\title{
Evaluating the Validity and Utility of Wearable Technology for Continuously Monitoring Patients in a Hospital Setting: Systematic Review
}

Vikas Patel ${ }^{1}$, BMSc, MD; Ani Orchanian-Cheff ${ }^{2}$, BA, MISt; Robert $\mathrm{Wu}^{1,3}, \mathrm{MSc}, \mathrm{MD}$, FRCPC

${ }^{1}$ Faculty of Medicine, University of Toronto, Toronto, ON, Canada

${ }^{2}$ Library and Information Services, University Health Network, Toronto, ON, Canada

${ }^{3}$ Division of General Internal Medicine, University Health Network, Toronto, ON, Canada

Corresponding Author:

Vikas Patel, BMSc, MD

Faculty of Medicine

University of Toronto

1 King's College Cir

Toronto, ON, M5S 1A8

Canada

Phone: 14169756585

Email: vik.patel@mail.utoronto.ca

\section{Abstract}

Background: The term posthospital syndrome has been used to describe the condition in which older patients are transiently frail after hospitalization and have a high chance of readmission. Since low activity and poor sleep during hospital stay may contribute to posthospital syndrome, the continuous monitoring of such parameters by using affordable wearables may help to reduce the prevalence of this syndrome. Although there have been systematic reviews of wearables for physical activity monitoring in hospital settings, there are limited data on the use of wearables for measuring other health variables in hospitalized patients.

Objective: This systematic review aimed to evaluate the validity and utility of wearable devices for monitoring hospitalized patients.

Methods: This review involved a comprehensive search of 7 databases and included articles that met the following criteria: inpatients must be aged $>18$ years, the wearable devices studied in the articles must be used to continuously monitor patients, and wearables should monitor biomarkers other than solely physical activity (ie, heart rate, respiratory rate, blood pressure, etc). Only English-language studies were included. From each study, we extracted basic demographic information along with the characteristics of the intervention. We assessed the risk of bias for studies that validated their wearable readings by using a modification of the Consensus-Based Standards for the Selection of Health Status Measurement Instruments.

Results: Of the 2012 articles that were screened, 14 studies met the selection criteria. All included articles were observational in design. In total, 9 different commercial wearables for various body locations were examined in this review. The devices collectively measured 7 different health parameters across all studies (heart rate, sleep duration, respiratory rate, oxygen saturation, skin temperature, blood pressure, and fall risk). Only 6 studies validated their results against a reference device or standard. There was a considerable risk of bias in these studies due to the low number of patients in most of the studies (4/6, 67\%). Many studies that validated their results found that certain variables were inaccurate and had wide limits of agreement. Heart rate and sleep were the parameters with the most evidence for being valid for in-hospital monitoring. Overall, the mean patient completion rate across all 14 studies was $>90 \%$.

Conclusions: The included studies suggested that wearable devices show promise for monitoring the heart rate and sleep of patients in hospitals. Many devices were not validated in inpatient settings, and the readings from most of the devices that were validated in such settings had wide limits of agreement when compared to gold standards. Even some medical-grade devices were found to perform poorly in inpatient settings. Further research is needed to determine the accuracy of hospitalized patients' digital biomarker readings and eventually determine whether these wearable devices improve health outcomes.

(JMIR Mhealth Uhealth 2021;9(8):e17411) doi: 10.2196/17411 


\section{KEYWORDS}

wearable; inpatient; continuous monitoring

\section{Introduction}

\section{Background}

Most physiologic parameters, such as vital signs or activity, are routinely monitored a few times each day in hospital ward settings [1]. Some parameters, such as sleep, are not routinely monitored at all $[2,3]$. More frequent monitoring could allow for the timely identification of the deteriorating health of patients and spur efforts for improving patients' overall health through increased sleep and activity. Since subtle changes in vital signs are often present 8 to 24 hours before a life-threatening event, such as intensive care unit admission or cardiac arrest, vital sign surveillance has the potential to detect clinical deterioration at an earlier phase, thereby permitting clinicians to make corrective interventions [4-7]. This includes identifying patients with poorly controlled pain and recognizing arrhythmias. The term posthospital syndrome has been used to denote the deleterious effects of acute illnesses that are compounded with poor sleep and low activity and occur during hospital stay [8]. Measuring sleep and activity could improve the recognition of such issues and encourage health providers to introduce interventions that improve patients' experiences in hospitals by encouraging mobilization and to identify targets for sleep-promoting interventions [9-11]. In addition, access to other digital biomarkers (eg, heart rate, blood pressure, oxygen saturation, etc) would allow clinicians to determine underlying etiologies and make tailored interventions.

The rapid uptake of affordable wearables, such as fitness bands, may provide a method for continuously measuring sleep; activity; and vital signs, such as heart rate [12-15]. However, existing literature that describes wearable devices is mostly limited to ambulatory settings and focuses on the management of chronic diseases [16,17]. More inpatient data are needed on both the validity of wearables and patient adherence. Although wearable testing has been conducted with healthy volunteers, it will be important to validate these signals in inpatient settings, where algorithms for processing sensor data into digital signals, such as those for sleep, heart rate, and activity, may be less accurate [18]. Despite the proposed benefit of intensive monitoring, many wearable studies have found issues with patient adherence [18-20]. Adherence is a crucial barrier to acquiring data and can be influenced by device convenience, the comfort of use, and interaction requirements [19]. Studies of wearable devices worn by hospitalized inpatients have been limited by large dropout rates [20].

Although there have been systematic reviews of the monitoring of patients' physical activity in hospitals [21-23], there are no reviews of the use of wearables that can reliably measure other health parameters. Therefore, in this review, we aimed to expand our search by including articles that used wearables to assess parameters other than physical activity and to assess the adherence of patients in inpatient settings.

\section{Objective}

For the purposes of this review, a wearable was considered to be any electronic device that has at least 1 sensor and can be worn on the body [24]. Wearables were examined for their ability to measure digital biomarkers, which are defined as digitally collected physiological and behavioral measures (eg, heart rate, average sleep duration, and daily step count) that explain, influence, or predict health-related outcomes [18]. Consistent with previous research, patient adherence was objectively assessed by reporting the mean proportion of patients who completed a given study [25]. The primary objectives of this review were to determine patients' adherence to using wearable devices in hospitals and to examine the validity of wearable-derived biomarker readings.

\section{Methods}

\section{Identification and Selection of Studies}

A comprehensive search strategy was developed to identify articles on the three main concepts of our question-wearables, monitoring, and inpatients. The initial search strategy was developed for Ovid MEDLINE by using a combination of database-specific subject headings and text words (Multimedia Appendix 1). Additional key words were generated based on input from the subject specialists on the team, and the revised search strategy was customized for each database.

Searches of the following databases were executed on August 16, 2018: Ovid MEDLINE, Ovid MEDLINE Epub Ahead of Print and In-Process \& Other Non-Indexed Citations, Cochrane Database of Systematic Reviews, Cochrane Central Register of Controlled Trials, Health Technology Assessment database (Ovid), and CINAHL with Full Text. The search in Ovid Embase was not executed until September 5, 2018, due to issues with the vendor's August database reload. Additional search methods included reviewing the cited references of eligible studies via Web of Science (May 6, 2019) and the reference lists of eligible studies. There were no restrictions on publication period. Limits were imposed to ensure that only English-language studies and those with adult populations were included in this review. No other limits were applied to the literature search.

\section{Article Selection and Exclusion Criteria}

Records were screened by two reviewers (VP and RW) independently. For selected studies, full-text articles were obtained and evaluated for eligibility [26]. The eligibility criteria for inclusion in this review were as follows:

- Medical or surgical inpatients aged $>18$ years

- Device studied in the article must be a wearable (such as a watch, vest, pendant, jewelry, headset, and wristband)

- Articles must describe an element of continuous monitoring for at least 24 hours or greater

- Articles must describe the measurement of 1 or more digital biomarkers other than just physical activity or standard hospital telemetry for heart rate recording. 
We excluded articles that were not considered original research, such as letters to the editor, comments, and reviews. We also excluded articles that monitored less than 3 patients, described the monitoring of a very specialized system in the body (eg, insole devices, ventricular assistive devices, and cochlear implants), involved the monitoring of patients in rehabilitation hospitals, or used wearables as tools for therapy (eg, insulin delivery).

\section{Data Extraction}

Two reviewers (RW and VP) independently extracted the data and resolved any disagreements by discussing the findings and making a collective decision. The data extracted for each article included the year of publication, study setting and design, number of participants, gender ratio, mean age of participants, digital biomarkers measured in the study, average and maximum duration that the wearable was worn by participants in each study, and patient completion rate (the proportion of patients that wore the wearable for the minimum monitoring duration that was set by the study authors). For studies that used a reference standard, any participants who were missing data from the wearable or the standard were determined to be incomplete measurement pairs and were omitted from the final count of patients who completed the study. Furthermore, we extracted the types of wearables that were worn by the participants in each study along with the placement sites on the body. Devices were classified as medical grade (approved or cleared by the US Food and Drug Administration), research grade (typically used in research settings only), and consumer grade (used by general consumers).

Validation data were also collected for each article by assessing whether the authors compared the accuracy of their digital readings to a reference standard. To determine the validity of measures that were compared to a reference standard, correlation coefficients, mean differences, and limits of agreement were extracted from each study.

\section{Risk of Bias Assessment}

All articles that assessed for validated readings were independently assessed for their risk of bias by two independent reviewers (VP and RW) using a modification of the validation subscale from a checklist for assessing the methodological quality of studies on the measurement properties of health status measurement instruments (Consensus-Based Standards for the Selection of Health Status Measurement Instruments [COSMIN]) [27] (Table 1). All discrepancies were resolved by discussion and consensus. The quality evaluation included 5 study design and methodology components (the percentage of missing data, missing data management, adequate sample size, acceptable criterion comparison, and design or methodological flaws) and 1 analysis component (acceptable accuracy analyses). We rated the quality of each dimension as excellent, good, fair, or poor based on a priori modifications to the COSMIN validation subscale for scoring criteria that are appropriate for accuracy studies (Multimedia Appendix 2) [28].

Table 1. Risk of bias assessment for studies that validated their wearable readings.

\begin{tabular}{|c|c|c|c|c|c|c|c|c|c|c|}
\hline \multirow[t]{2}{*}{ Study } & \multicolumn{10}{|c|}{ Assessment criterion } \\
\hline & $\begin{array}{l}\text { Mean or \% } \\
\text { difference }\end{array}$ & $\begin{array}{l}\text { Corre- } \\
\text { lation }\end{array}$ & $\mathrm{LOA}^{\mathrm{a}}$ & $\begin{array}{l}\text { Percentage of } \\
\text { missing data }\end{array}$ & $\begin{array}{l}\text { Missing } \\
\text { data man- } \\
\text { agement }\end{array}$ & $\begin{array}{l}\text { Adequate } \\
\text { sample size } \\
\text { (patients) }\end{array}$ & $\begin{array}{l}\text { Adequate } \\
\text { sample size } \\
\text { (measure- } \\
\text { ments) }\end{array}$ & $\begin{array}{l}\text { Acceptable } \\
\text { reference } \\
\text { comparison }\end{array}$ & $\begin{array}{l}\text { Other } \\
\text { method- } \\
\text { ological } \\
\text { flaws }\end{array}$ & $\begin{array}{l}\text { Acceptable } \\
\text { accuracy } \\
\text { analyses }\end{array}$ \\
\hline Bloch et al [29] & No & No & No & Excellent & Excellent & Poor & Poor & Excellent & No & Poor \\
\hline Breteler et al [30] & Yes & No & Yes & Excellent & Excellent & Poor & Excellent & Excellent & No & Excellent \\
\hline Gallo and Lee [13] & No & Yes & No & Excellent & Excellent & Fair & Fair & Fair & No & Excellent \\
\hline Kroll et al $[11,31]$ & Yes & Yes & Yes & Excellent & Excellent & Good & Excellent & Excellent & No & Excellent \\
\hline Steinhubl et al [32] & No & Yes & No & Excellent & Excellent & Poor & Excellent & Excellent & No & Excellent \\
\hline Weenk et al [4] & Yes & No & Yes & Excellent & Excellent & Poor & Good & Excellent & No & Excellent \\
\hline
\end{tabular}

${ }^{a}$ LOA: limits of agreement.

\section{Results}

\section{Characteristics of Included Studies}

Our literature search identified 2754 article citations. After excluding duplicate records, 2012 records were deemed eligible for screening. A total of 83 studies were selected based on abstracts and underwent full-text review. After applying our inclusion and exclusion criteria, 15 articles that described 14 studies were selected for this review (Figure 1). 
Figure 1. PRISMA (Preferred Reporting Items for Systematic Reviews and Meta-Analyses) flow diagram of included and excluded studies.

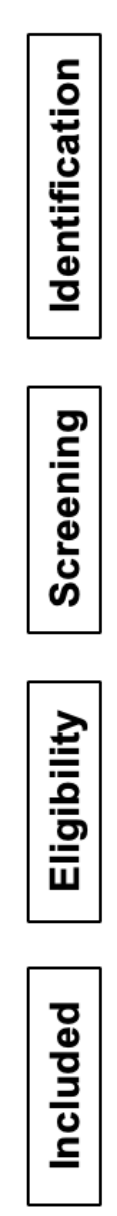

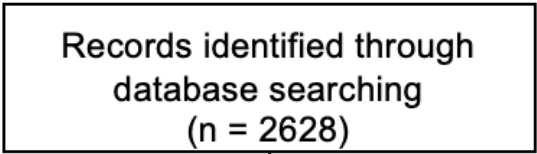

$(n=2628)$

\section{Additional records identified through other sources $(n=126)$}

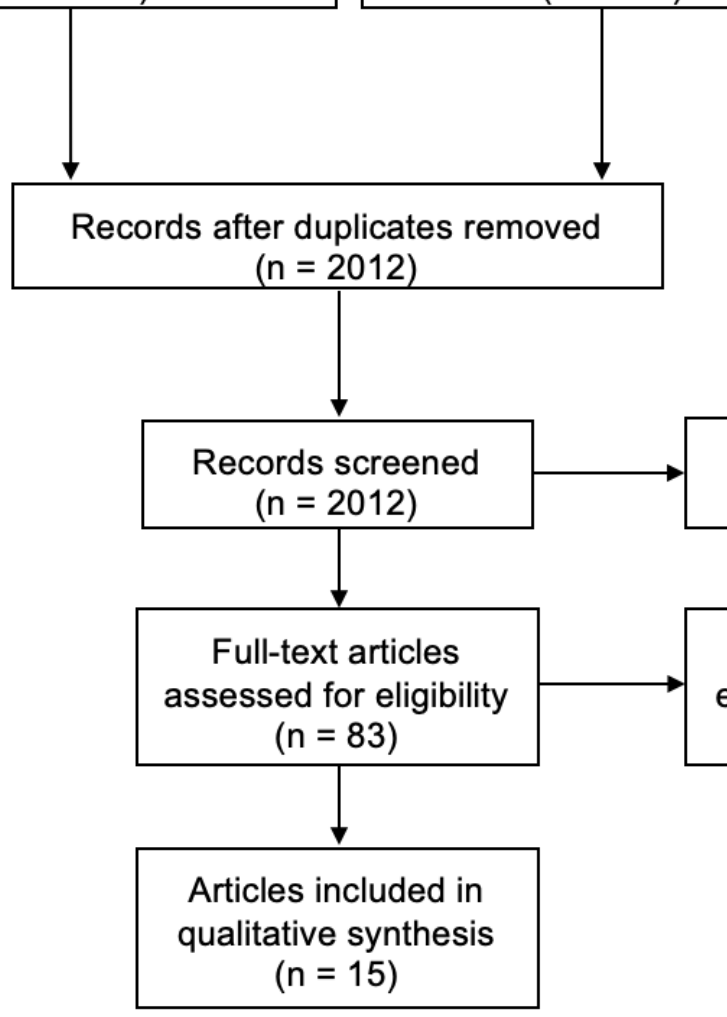

Records excluded $(n=1929)$

Full-text articles excluded, with reasons $(n=68)$
All of the articles included were prospective cohort studies (Table 2) [4,11,13,14,20,29-38]. Overall, 9 different types of commercial wearables were described across the 14 studies, and 7 different health variables were assessed collectively by the 14 studies (Table 3). The wearable devices that were described by the studies came in various different forms and were attached to a range of sites on the body (Figure 2). A total of 13 articles included both men and women as the study participants; the other two papers assessed sleep changes in postpartum women [13,34]. Kroll et al [11,31] published two articles from the same study. Both articles analyzed different aspects of the continuous monitoring of inpatients (ie, they used the same cohort of patients) but were included as the same study entry in this review (Table 2).

Collectively, the mean patient completion rate across all 14 studies was over $90 \%$. Of the 8 articles that included a qualitative analysis as a part of their methodology, 7 reported that wearables were well received by either or both patients and clinicians.
Of the 14 studies, 6 validated wearable measurements against another standard device or measure (Table 3). The studies conducted by Bloch et al [29], Gallo and Lee [13], and Steinhubl et al [32] used intermittent measurements (nurse or questionnaires) for their reference standard. Further, Breteler et al [30] used a continuous reference (continuous electrocardiography and impedance pneumography) to compare the wearable readings for heart rates and respiratory rates [30]. Weenk et al [4] and Kroll et al [11,31] validated their wearable readings against both intermittent and continuous reference measurements. Of the 9 wearables included in the studies, 6 were cleared or approved by the US Food and Drug Administration as medical devices (ViSi Mobile [Sotera Wireless], Hidalgo EQ02 [Equivital], wrist actigraphy [Ambulatory Monitoring Inc; Actigraph LLC], LifeTouch [Isansys Lifecare], Zephyr Biopatch [Medtronic], and HealthPatch [VitalConnect]). 
Table 2. Summary of included studies.

\begin{tabular}{|c|c|c|c|c|c|c|c|c|}
\hline Study & $\begin{array}{l}\text { Year pub- } \\
\text { lished }\end{array}$ & Setting (ward) & Methodology & $\begin{array}{l}\text { Patients, } \\
\mathrm{N}\end{array}$ & $\begin{array}{l}\text { Male \%: Female } \\
\% \text { ratio, mean } \\
\text { age (years) }\end{array}$ & Variables measured & $\begin{array}{l}\text { Number of } \\
\text { days device } \\
\text { was worn, } \\
\text { average } \\
\text { (maximum) }\end{array}$ & $\begin{array}{l}\text { Patient } \\
\text { completion } \\
\text { rate, } \%\end{array}$ \\
\hline Lee and Lee [34] & 2007 & Obstetric & $\begin{array}{l}\text { Prospective } \\
\text { cohort }\end{array}$ & 21 & Females only, 32 & Sleep & $2^{\mathrm{a}}$ & 100 \\
\hline Gallo and Lee [13] & 2008 & Obstetric & $\begin{array}{l}\text { Prospective } \\
\text { cohort }\end{array}$ & 39 & Females only, 29 & Sleep & $2(2)$ & 100 \\
\hline Bloch et al [29] & 2011 & Geriatric & $\begin{array}{l}\text { Prospective } \\
\text { cohort }\end{array}$ & 10 & $\begin{array}{l}\text { Males and fe- } \\
\text { males }^{\text {b }}, 83\end{array}$ & Falls & $21^{\mathrm{a}}$ & 90 \\
\hline Chiu et al [33] & 2013 & Neurosurgery & $\begin{array}{l}\text { Prospective } \\
\text { cohort }\end{array}$ & 60 & $65: 35,35$ & Sleep & $7^{\mathrm{a}}$ & 87 \\
\hline Watkins et al [37] & 2015 & $\begin{array}{l}\text { Medicine and } \\
\text { surgical }\end{array}$ & $\begin{array}{l}\text { Prospective } \\
\text { cohort }\end{array}$ & 236 & $\begin{array}{l}\text { Males and fe- } \\
\text { males }^{\text {b,c }}\end{array}$ & $\begin{array}{l}\mathrm{HR}^{\mathrm{d}}, \mathrm{RR}^{\mathrm{e}}, \mathrm{SpO}_{2}{ }^{\mathrm{f}} \text {, } \\
\text { and } \mathrm{BP}^{\mathrm{g}}\end{array}$ & $3(3)$ & 100 \\
\hline Jeffs et al [20] & 2016 & Medicine & $\begin{array}{l}\text { Prospective } \\
\text { cohort }\end{array}$ & 208 & $72: 28^{\mathrm{c}}$ & $\begin{array}{l}\mathrm{HR} . \mathrm{RR}, \mathrm{SpO}_{2} \text {, tem- } \\
\text { perature, and ac- } \\
\text { celerometry }\end{array}$ & $(14)^{h}$ & 32 \\
\hline Steinhubl et al [32] & 2016 & Medicine & $\begin{array}{l}\text { Prospective } \\
\text { cohort }\end{array}$ & 26 & $65: 35,33$ & $\begin{array}{l}\mathrm{HR}, \mathrm{RR} \text {, and temper- } \\
\text { ature }\end{array}$ & $3(3)$ & 100 \\
\hline $\begin{array}{l}\text { Razjouyan et al } \\
{[35]}\end{array}$ & 2017 & $\begin{array}{l}\text { Hematology } \\
\text { and } \\
\text { oncology }\end{array}$ & $\begin{array}{l}\text { Prospective } \\
\text { cohort }\end{array}$ & 35 & $45: 55,55$ & HR and fall risk & $1^{\mathrm{a}}$ & 94 \\
\hline Weenk et al [4] & 2017 & $\begin{array}{l}\text { General internal } \\
\text { medicine and } \\
\text { surgical }\end{array}$ & $\begin{array}{l}\text { Prospective } \\
\text { cohort }\end{array}$ & 20 & $65: 35,50$ & $\begin{array}{l}\mathrm{HR}, \mathrm{RR}, \mathrm{BP}, \mathrm{SpO}_{2} \text {, } \\
\text { and temperature }\end{array}$ & $2.5(3)$ & 100 \\
\hline Kroll et al $[11,31]$ & 2017 & $\begin{array}{l}\text { Intensive care } \\
\text { unit }\end{array}$ & $\begin{array}{l}\text { Prospective } \\
\text { cohort }\end{array}$ & 50 & $52: 48,64$ & HR, sleep & $1^{\mathrm{a}}$ & 96 \\
\hline Weller et al [36] & 2017 & $\begin{array}{l}\text { Neurology and } \\
\text { neurosurgery }\end{array}$ & $\begin{array}{l}\text { Prospective } \\
\text { cohort }\end{array}$ & 736 & $54: 46^{\mathrm{c}}$ & $\begin{array}{l}\mathrm{HR}, \mathrm{RR}, \mathrm{SpO}_{2} \text {, and } \\
\mathrm{BP}\end{array}$ & $1.7(9)$ & 100 \\
\hline Breteler et al [30] & 2018 & Surgical & $\begin{array}{l}\text { Prospective } \\
\text { cohort }\end{array}$ & 33 & $72: 28,63$ & $\mathrm{HR}$ and $\mathrm{RR}$ & $2.6(3)$ & 76 \\
\hline Yang et al [14] & 2018 & Oncology & $\begin{array}{l}\text { Prospective } \\
\text { cohort }\end{array}$ & 11 & $64: 36^{\mathrm{c}}$ & Sleep & $16^{\mathrm{a}}$ & 91 \\
\hline Duus et al [38] & 2018 & $\begin{array}{l}\text { General } \\
\text { surgery }\end{array}$ & $\begin{array}{l}\text { Prospective } \\
\text { cohort }\end{array}$ & 50 & $58: 42,71$ & $\mathrm{HR}, \mathrm{RR}$, and $\mathrm{SpO}_{2}$ & $3.1(4)$ & 100 \\
\hline
\end{tabular}

${ }^{\mathrm{a}}$ The maximum number of days was not reported in the study.

${ }^{b}$ The study included both male and female participants but did not report a ratio.

${ }^{\mathrm{c}}$ Mean age was not reported in the study.

${ }^{\mathrm{d}} \mathrm{HR}$ : heart rate.

${ }^{\mathrm{e}} \mathrm{RR}$ : respiratory rate.

${ }^{\mathrm{f}} \mathrm{SpO}_{2}$ : oxygen saturation

$\mathrm{g}_{\mathrm{BP}}$ : blood pressure.

${ }^{\mathrm{h}}$ The average number of days was not reported in the study. 
Table 3. Distribution of the health variables that were assessed for accuracy in each study.

\begin{tabular}{|c|c|c|c|c|c|c|c|c|c|}
\hline \multirow[t]{2}{*}{ Study } & \multicolumn{2}{|l|}{ Device characteristics } & \multicolumn{7}{|c|}{ Digital biomarkers } \\
\hline & Device, manufacturer & $\begin{array}{l}\text { FDA }^{\mathrm{a}} \text { clearance } \\
\text { or approval }\end{array}$ & Heart rate & Sleep & $\begin{array}{l}\text { Respirato- } \\
\text { ry rate }\end{array}$ & $\mathrm{SpO}_{2}{ }^{\mathrm{b}}$ & $\begin{array}{l}\text { Skin tem- } \\
\text { perature }\end{array}$ & $\begin{array}{l}\text { Blood } \\
\text { pressure }\end{array}$ & Fall risk \\
\hline Gallo and Lee [13] & $\begin{array}{l}\text { Wrist Actigraph, Ambu- } \\
\text { latory Monitoring Inc }\end{array}$ & Yes & $-^{\mathrm{c}}$ & $R=0.53$ & - & - & - & - & - \\
\hline Lee and Lee [34] & $\begin{array}{l}\text { Mini-Motionlogger- } \\
\text { Actigraphy, Ambulato- } \\
\text { ry Monitoring Inc }\end{array}$ & Yes & - & $\begin{array}{l}\text { Not vali- } \\
\text { dated }\end{array}$ & - & - & - & - & - \\
\hline Chiu et al [33] & $\begin{array}{l}\text { ActiGraph GT1M, } \\
\text { Actigraph LLC }\end{array}$ & Yes & - & $\begin{array}{l}\text { Not vali- } \\
\text { dated }\end{array}$ & - & - & - & - & - \\
\hline Yang et al [14] & $\begin{array}{l}\text { Actigraph GT3X+ } \\
\text { watch, Actigraph LLC }\end{array}$ & Yes & - & $\begin{array}{l}\text { Not vali- } \\
\text { dated }\end{array}$ & - & - & - & - & - \\
\hline Kroll et al [11,31] & $\begin{array}{l}\text { Fitbit Charge HR, Fitbit } \\
\text { Inc }\end{array}$ & - & $\begin{array}{l}\text { LoA }^{\mathrm{d}}\left(\mathrm{si}^{-}\right. \\
\text {nus): } 23.9 \\
\text { to } 21.9 \\
\text { beats per } \\
\text { minute }\end{array}$ & $R=0.33$ & - & - & - & - & - \\
\hline Breteler et al [30] & $\begin{array}{l}\text { HealthPatch, VitalCon- } \\
\text { nect }\end{array}$ & Yes & $\begin{array}{l}\text { LoA: }-8.8 \\
\text { to } 6.5 \text { beats } \\
\text { per minute }\end{array}$ & - & $\begin{array}{l}\text { LoA: } \\
-15.8 \text { to } \\
11.2 \\
\text { breaths } \\
\text { per } \\
\text { minute }\end{array}$ & - & $\begin{array}{l}\text { Not vali- } \\
\text { dated }\end{array}$ & - & $\begin{array}{l}\text { Not vali- } \\
\text { dated }\end{array}$ \\
\hline Jeffs et al [20] & $\begin{array}{l}\text { Hidalgo EQ02, Equivi- } \\
\text { tal }\end{array}$ & Yes & $\begin{array}{l}\text { Not validat- } \\
\text { ed }\end{array}$ & - & $\begin{array}{l}\text { Not vali- } \\
\text { dated }\end{array}$ & $\begin{array}{l}\text { Not vali- } \\
\text { dated }\end{array}$ & $\begin{array}{l}\text { Not vali- } \\
\text { dated }\end{array}$ & - & - \\
\hline Duus et al [38] & $\begin{array}{l}\text { LifeTouch, Isansys } \\
\text { Lifecare }\end{array}$ & Yes & $\begin{array}{l}\text { Not validat- } \\
\text { ed }\end{array}$ & - & $\begin{array}{l}\text { Not vali- } \\
\text { dated }\end{array}$ & $\begin{array}{l}\text { Not vali- } \\
\text { dated }\end{array}$ & - & - & - \\
\hline $\begin{array}{l}\text { Steinhubl et al } \\
{[32]^{\mathrm{e}}}\end{array}$ & $\begin{array}{l}\text { MultiSense patch, } \\
\text { Rhythm Diagnostic } \\
\text { Systems }\end{array}$ & - & $R=0.75$ & - & $R=0.83$ & - & $R=0.99$ & - & - \\
\hline Bloch et al [29] & $\begin{array}{l}\text { Vigi'Fall, Vigilio } \\
\text { Telemedical }\end{array}$ & - & - & - & - & - & - & - & $\begin{array}{l}\text { Sensitivi- } \\
\text { ty: } 37.5 \%\end{array}$ \\
\hline Weenk et al [4] & $\begin{array}{l}\text { ViSi Mobile, Sotera } \\
\text { Wireless }\end{array}$ & Yes & $\begin{array}{l}\text { LoA: }-11.1 \\
\text { to } 10.7 \\
\text { beats per } \\
\text { minute }\end{array}$ & - & $\begin{array}{l}-5.5 \text { to } \\
7.9 \\
\text { breaths } \\
\text { per } \\
\text { minute }\end{array}$ & $\begin{array}{l}-3.1 \% \text { to } \\
3.3 \%\end{array}$ & $\begin{array}{l}\text { Not vali- } \\
\text { dated }\end{array}$ & $\begin{array}{l}\mathrm{SBP}^{\mathrm{f}} \text { : } \\
-23 \text { to } 24 \\
\mathrm{~mm} \mathrm{Hg} ; \\
\mathrm{DBP}^{\mathrm{g}} \text { : } \\
27.5 \text { to } \\
11.5 \mathrm{~mm} \\
\mathrm{Hg}\end{array}$ & - \\
\hline Weenk et al [4] & $\begin{array}{l}\text { HealthPatch, VitalCon- } \\
\text { nect }\end{array}$ & Yes & $\begin{array}{l}-12.6 \text { to } \\
9.5 \text { beats } \\
\text { per minute }\end{array}$ & - & $\begin{array}{l}-10.3 \text { to } \\
9.0 \\
\text { breaths } \\
\text { per } \\
\text { minute }\end{array}$ & $\begin{array}{l}\text { Not vali- } \\
\text { dated }\end{array}$ & $\begin{array}{l}\text { Not vali- } \\
\text { dated }\end{array}$ & $\begin{array}{l}\text { Not vali- } \\
\text { dated }\end{array}$ & - \\
\hline Weller et al [36] & $\begin{array}{l}\text { ViSi Mobile, Sotera } \\
\text { Wireless }\end{array}$ & Yes & $\begin{array}{l}\text { Not validat- } \\
\text { ed }\end{array}$ & - & $\begin{array}{l}\text { Not vali- } \\
\text { dated }\end{array}$ & $\begin{array}{l}\text { Not vali- } \\
\text { dated }\end{array}$ & $\begin{array}{l}\text { Not vali- } \\
\text { dated }\end{array}$ & $\begin{array}{l}\text { Not vali- } \\
\text { dated }\end{array}$ & - \\
\hline Watkins et al [37] & $\begin{array}{l}\text { ViSi Mobile, Sotera } \\
\text { Wireless }\end{array}$ & Yes & $\begin{array}{l}\text { Not validat- } \\
\text { ed }\end{array}$ & - & $\begin{array}{l}\text { Not vali- } \\
\text { dated }\end{array}$ & $\begin{array}{l}\text { Not vali- } \\
\text { dated }\end{array}$ & - & $\begin{array}{l}\text { Not vali- } \\
\text { dated }\end{array}$ & - \\
\hline $\begin{array}{l}\text { Razjouyan et al } \\
\text { [35] }\end{array}$ & $\begin{array}{l}\text { Zephyr BioPatch, } \\
\text { Medtronic }\end{array}$ & Yes & $\begin{array}{l}\text { Not validat- } \\
\text { ed }\end{array}$ & - & - & - & - & - & $\begin{array}{l}\text { Not vali- } \\
\text { dated }\end{array}$ \\
\hline
\end{tabular}

${ }^{\mathrm{a}}$ FDA: US Food and Drug Administration.

${ }^{\mathrm{b}} \mathrm{SpO}_{2}$ : oxygen saturation.

${ }^{c}$ Not available.

${ }^{\mathrm{d}}$ LOA: limits of agreement.

${ }^{\mathrm{e}}$ Steinhubl et al [32] did not report limits of agreement. 
${ }^{\mathrm{f}} \mathrm{SBP}$ : systolic blood pressure.

${ }^{\mathrm{g}}$ DBP: diastolic blood pressure.

Figure 2. Illustration of the types of and body locations for used wearable devices.

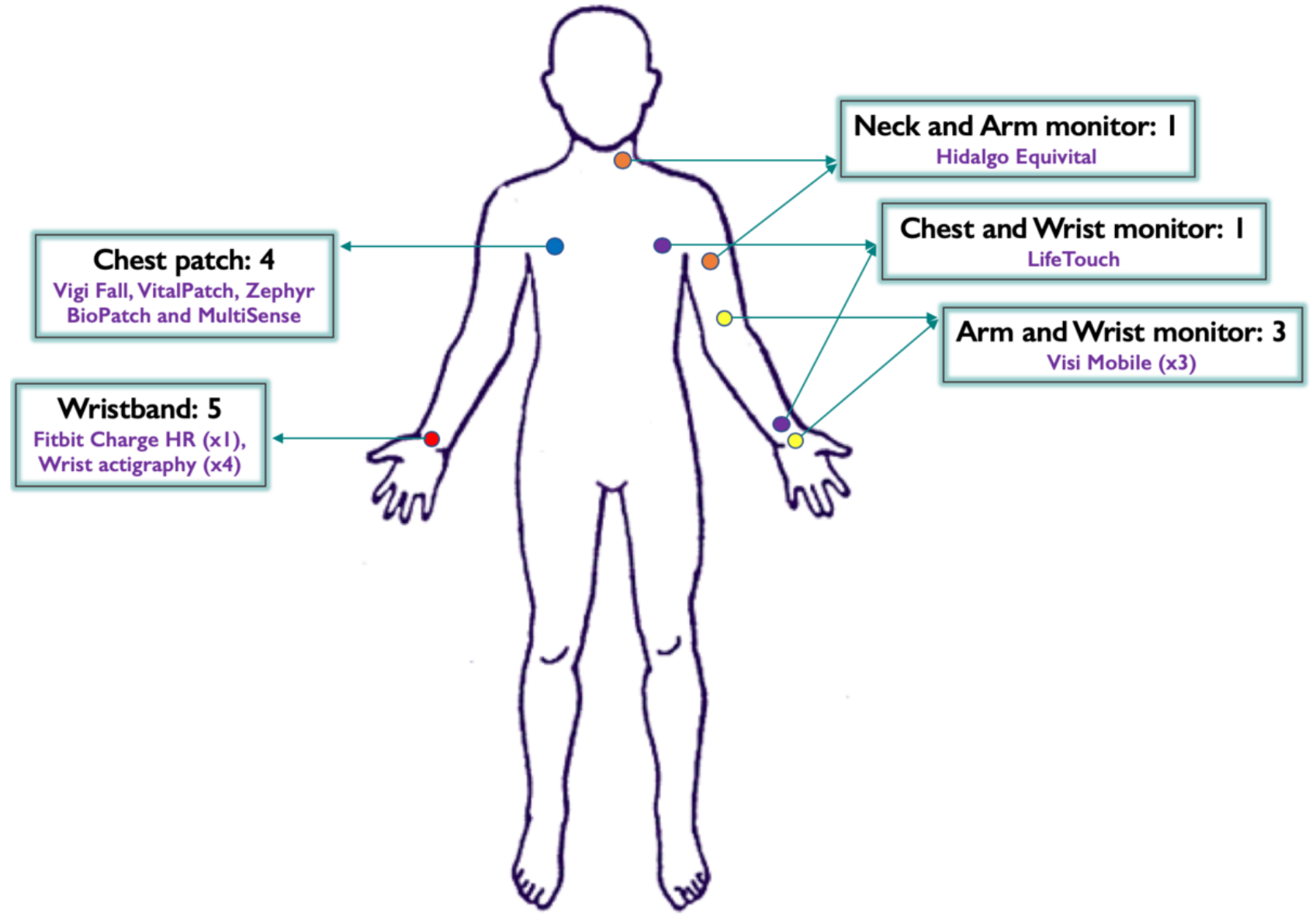

\section{Risk of Bias}

Of the 6 studies in the risk of bias assessment, 4 were ranked as poor due to a small sample size (participants: $\mathrm{N}<30$ ). The study conducted by Gallo and Lee [13] used sleep questionnaires as a reference measure and therefore received a fair rating for the "acceptability of reference" criterion, whereas the other five studies were ranked as excellent (ie, they used intermittent nurse readings or other validated methodologies). Further, in terms of assessing the accuracy analyses, only the study conducted by Bloch et al [29] did not report mean differences, correlations, and limits of agreement.

\section{Validation by Digital Biomarker}

\section{Heart Rate}

A total of 5 studies assessed heart rate accuracy. Breteler et al [30] found that the bias and $95 \%$ limits of agreement for heart rate were -1.1 beats per minute (BPM) and -8.8 to $6.5 \mathrm{BPM}$, respectively, for 55,565 heart rate pairs [30]. Specifically, the wearable sensor accurately detected tachycardia with a sensitivity of $90 \%$ and a specificity of $97 \%$ [30]. In a cohort of intensive care unit patients, Kroll et al [11,31] found that the Fitbit (Fitbit Inc)-derived heart rate values were slightly lower than those derived from continuous electrocardiography monitoring but that $73 \%$ of the readings were within $5 \mathrm{BPM}$ of the electrocardiogram value (average bias: $-1.14 \mathrm{BPM} ; R=0.74$; $P<.001$; heart rate pairs: $\mathrm{n}=12,358$ ) [11]. Overall, the limit of agreement for the Fitbit device was 24 BPM, but its performance was significantly better in patients in sinus rhythm than in those who were not in sinus rhythm (average bias: -0.99 BPM vs -5.02 BPM, respectively; $P=.02$; limits of agreement: 22.9 BPM vs $46.4 \mathrm{BMP}$, respectively; $P=.049)$ [11]. Kroll et al [11,31] also found that the Fitbit was very specific when it detected tachycardia (sensitivity $=70 \%$; specificity $=99 \%$ ) [31]. Steinhubl et al [32] demonstrated that manual and automated heart rate readings correlated well $(R=0.75$; measurements: $\mathrm{n}=111)$, but limits of agreement were not reported [32]. Weenk et al [4] reported that heart rate readings were generally consistent when compared to the nurse recordings; the limits of agreement for the ViSi Mobile and the HealthPatch were -11.1 to 10.7 BPM and -12.6 to 9.5 BPM, respectively (86 measurements).

\section{Sleep}

A total of 6 studies used wearables to assess sleep, of which 2 assessed whether wearable readings were reliable. Gallo and Lee [13] found that self-reported sleep correlated with the actigraphy-recorded number of awakenings $(R=0.53 ; P=.01)$ [13]. Kroll et al [11,31] found that there was a moderate correlation between wearable-derived sleep duration and questionnaire-derived sleep quality $(R=0.33 ; P=.03)$ [31]. 


\section{Respiratory Rate}

Of the 8 articles that used different wearables to measure the respiratory rate of patients, 3 assessed the wearables' accuracy. Breteler et al [30] found that for respiratory rate, the bias was -2.3 breaths per minute, and wide limits of agreement were reported ( -15.8 to 11.2 breaths per minute; measurement pairs: $\mathrm{n}=56,674)$ [30]. Steinhubl et al [32] reported that there was a strong correlation between wearable and manual respiratory rate readings $(R=0.83 ; P<.001$; measurements: $\mathrm{n}=111)$, but limits of agreement were not reported [32]. Weenk et al [4] described wide limits of agreement for respiratory rate based on 86 measurements (ViSi Mobile limits of agreement: -5.5 to 7.9 breaths per minute; HealthPatch limits of agreement: -10.3 to 9.0 breaths per minute) [4].

\section{Other Measures}

Only 1 study, which was conducted by Weenk et al [4], assessed the accuracy of oxygen saturation and blood pressure readings from ViSi Mobile by comparing them to HealthPatch readings as well as intermittent nurse measurements. From 86 measurements, they found that the automated readings for the systolic blood pressure, diastolic blood pressure, and oxygen saturation had wide limits of agreement (systolic blood pressure: -23.1 to $24.0 \mathrm{~mm} \mathrm{Hg}$; diastolic blood pressure: -27.5 to 11.5 mm Hg; oxygen saturation: $-3.1 \%$ to $3.3 \%$ ) [4]. Of the 6 articles that used wearables that measured skin temperature, only Steinhubl et al [32] validated the results against a reference standard to conclude that the automated readings were reliable ( $R=0.99 ; \mathrm{n}=112$ ), but bias and limits of agreement were not reported [32]. Of the 3 articles in this review that detected falls by using wearables, only Bloch and colleagues [29] assessed accuracy and found that the Vigi'Fall system had a low sensitivity (37.5\%) to fall risk [29].

\section{Discussion}

\section{Principal Findings}

We conducted a systematic review that evaluated the utility of wearable technology in continuously monitoring hospitalized patients for a wide variety of health parameters. Our review focused on the breadth of devices used and the signals measured in hospitalized patients and included consumer, research, and medical-grade devices. There was evidence to support the use of Fitbit, ViSi Mobile, and the HealthPatch to measure heart rate $[4,11,31]$, since the readings were validated against both intermittent and continuous reference standards. This review demonstrated that the validity of the data did not necessarily correlate with the classification of the device because even some medical-grade devices did not perform well and yielded data with wide limits of agreement. We found that only 6 studies validated the accuracy of wearable-derived health data from hospitalized patients by comparing the readings against a reference standard. Overall, the quality of most of these studies was excellent in terms of the reporting of missing data $(6 / 6$, $100 \%)$ and the use of acceptable accuracy evaluations (5/6, $83 \%$ ). However, there was a considerable risk of bias in these studies due to the low number of participants in most of the studies $(4 / 6,67 \%)$. Many studies reported wide limits of agreement for other digital biomarkers, such as respiratory rate and blood pressure. Of note, we also found that the majority of studies $(8 / 14,57 \%)$ did not validate the studied device or parameter measured.

Of the various health parameters, the best evidence of validity was in the monitoring of heart rate in hospitalized patients. We also found that, in hospital settings, limits of agreement for medical-grade devices ranged from 16.4 to $21.8 \mathrm{BPM}$, whereas the limit for a Fitbit consumer device that uses photoplethysmography signals was 24 BPM. Further, during Fitbit-based continuous electrocardiogram monitoring, $73 \%$ of the readings were within $5 \mathrm{BPM}$ of electrocardiogram readings. In a systematic review of 158 studies that measured heart rate by using consumer wearable devices, $71 \%$ and $51 \%$ of Apple Watch (Apple Inc) readings (used in 49 studies) and Fitbit readings (used in 71 studies), respectively, were within $3 \%$ of electrocardiogram readings in controlled settings [39]. Moreover, in 3 free-living studies, the wrist-worn Fitbit Charge had a mean absolute error percentage of $10 \%$ [39]. A systematic review of wrist-worn devices that measure heart rate via plethysmography found limits of agreement of 8.4 BPM at rest, 30.1 BPM while on a treadmill, and 41.5 BPM while cycling [40]. Overall, our findings found large limits of agreement for all devices, and inpatient results were consistent with the wide limits of agreement found in free-living environments or with activity.

We found that sleep only had a moderate correlation with sleep survey results from inpatient settings the use research and consumer devices. A recent systematic review of Fitbit-based sleep assessments found that readings from more recently developed devices correlated well with polysomnography readings for assessing sleep episodes [41]. It is unclear whether the lower correlation that we found was due to inpatient settings with high nighttime interruptions, patient factors that were perhaps associated with acute illness, or issues with sleep surveys (or a combination of these three factors) [3]. With respect to respiratory rate, 2 studies of 2 medical-grade devices provided limits of agreement. Wider limits of agreement were found in the study that had over 50,000 measurement pairs and used a gold standard ( 27 breaths per minute) compared to those in the study that had less than 100 measurement pairs and used clinician-reported vitals (13.4-19.3 breaths per minute) [30,32]. Additionally, previous studies found that medical-grade devices were only accurate under laboratory conditions or at-home conditions $[42,43]$. There was a limited number of studies on oxygen saturation, temperature, blood pressure, and fall risk.

\section{Limitations and Future Research}

There are a few limitations that should be noted for our systematic review. There is a considerable risk of bias, as the number of participants in the studies was low. Further, the studies included were observational in design and had a high degree of heterogeneity in terms of the objectives, populations, and outcomes reported. Thus, the data analysis methods were limited to broad categorization and the extraction of the common themes and trends that emerged from the results. Reports of wearable monitoring from individual studies should be viewed based on their methodological limitations. Although patient adherence has been found to correlate well with patients' 
acceptability of wearables devices in inpatient settings, we realize that studying factors such as data loss, the duration of data gaps, and qualitative feedback from nurses and patients would further strengthen the generalizability of the results. Finally, it is important to note that wearable studies are being increasingly performed, and more relevant articles will become increasingly available.

This review also identifies gaps in knowledge that still exist within literature and provides information about what is required for further research. Specifically, the further validation of digital biomarkers by using gold standard comparators, such as polysomnography for assessing sleep and continuous electrocardiogram monitoring for assessing heart rate, is required. Ideally, large participant sample sizes and large numbers of measurement pairs within a population of interest should be used to assess parameters such as vital signs. The use of 2 reference standards to validate each health parameter, such as a heart rate, has also been recommended [44]. Moreover, data that are derived under real life conditions are still needed to better understand the factors that may contribute to between-patient heterogeneity when comparing the accuracy of wearable readings, such as those for patient activity, posture, gait type and velocity, locations of wearables, and patients' diagnoses (eg, seizures). Future studies can aim to further qualify the process of retrieving data by using wearables to explore other barriers and avenues that might hinder the collection of reliable health information (ie, a weak Bluetooth connectivity, a lack of patient digital health literacy, the added burden that the process of taking wearable readings has on clinicians, the learning curve required to operate a wearable, etc) Finally, while we found that some digital biomarkers appeared to be valid for the monitoring of inpatients via wearables, we were unable to find any studies that supported the use of wearables in inpatient settings to improve clinical outcomes.

\section{Conclusions}

Overall, the assessment of studies in this review suggested that wearable devices show promise for monitoring the heart rate and sleep of patients in hospitals. The results show that many devices were not validated in inpatient settings, and the readings from most of the devices that were validated in such settings had wide limits of agreement. Further research is needed to determine the accuracy of the digital biomarker readings of hospitalized patients and to eventually determine whether wearable devices improve the health outcomes of hospitalized patients.

\section{Acknowledgments}

RW is supported by an award from the Mak Pak Chiu and Mak-Soo Lai Hing Chair of General Internal Medicine, University of Toronto. Funding for this study was kindly provided by the University Health Network Foundation Complex Care Fund.

\section{Authors' Contributions}

VP, AOC, and RW designed and planned the review. AOC conducted the search strategy. VP and RW screened the articles and conducted the data analysis. VP, AOC, and RW wrote and revised the manuscript.

\section{Conflicts of Interest}

None declared.

\section{Multimedia Appendix 1}

Search methods.

[DOCX File, 64 KB-Multimedia Appendix 1]

\section{Multimedia Appendix 2}

Modified Consensus-Based Standards for the Selection of Health Status Measurement Instruments (COSMIN) criteria used for the risk of bias assessment.

[DOCX File, 30 KB-Multimedia Appendix 2]

\section{References}

1. Mariani P, Saeed MU, Potti A, Hebert B, Sholes K, Lewis MJ, et al. Ineffectiveness of the measurement of 'routine' vital signs for adult inpatients with community-acquired pneumonia. Int J Nurs Pract 2006 Apr;12(2):105-109. [doi: 10.1111/j.1440-172X.2006.00556.x] [Medline: 16529596]

2. Kessler R, Knutson KL, Mokhlesi B, Anderson SL, Shah M, Meltzer DO, et al. Sleep and activity patterns in older patients discharged from the hospital. Sleep 2019 Oct 21;42(11):zsz153 [FREE Full text] [doi: 10.1093/sleep/zsz153] [Medline: $\underline{31310317]}$

3. Stewart NH, Arora VM. Sleep in hospitalized older adults. Sleep Med Clin 2018 Mar;13(1):127-135 [FREE Full text] [doi: 10.1016/i.jsmc.2017.09.012] [Medline: 29412979]

4. Weenk M, van Goor H, Frietman B, Engelen LJ, van Laarhoven CJ, Smit J, et al. Continuous monitoring of vital signs using wearable devices on the general ward: Pilot study. JMIR Mhealth Uhealth 2017 Jul 05;5(7):e91 [FREE Full text] [doi: 10.2196/mhealth.7208] [Medline: 28679490] 
5. Mapp ID, Davis LL, Krowchuk H. Prevention of unplanned intensive care unit admissions and hospital mortality by early warning systems. Dimens Crit Care Nurs 2013;32(6):300-309. [doi: 10.1097/DCC.0000000000000004] [Medline: 24100432]

6. Churpek MM, Yuen TC, Edelson DP. Predicting clinical deterioration in the hospital: the impact of outcome selection. Resuscitation 2013 May;84(5):564-568 [FREE Full text] [doi: 10.1016/j.resuscitation.2012.09.024] [Medline: 23022075]

7. Cretikos M, Chen J, Hillman K, Bellomo R, Finfer S, Flabouris A. The objective medical emergency team activation criteria: a case-control study. Resuscitation 2007 Apr;73(1):62-72. [doi: 10.1016/j.resuscitation.2006.08.020] [Medline: 17241732]

8. Krumholz HM. Post-hospital syndrome--an acquired, transient condition of generalized risk. N Engl J Med 2013 Jan 10;368(2):100-102 [FREE Full text] [doi: 10.1056/NEJMp1212324] [Medline: 23301730]

9. Alharbi M, Straiton N, Smith S, Neubeck L, Gallagher R. Data management and wearables in older adults: A systematic review. Maturitas 2019 Jun;124:100-110. [doi: 10.1016/j.maturitas.2019.03.012] [Medline: 30910279]

10. Whyman J. Post-hospital syndrome: Tips to keep yourself or a loved one healthy after hospitalization. Harvard Health Publishing. URL: https://www.health.harvard.edu/blog/

post-hospital-syndrome-tips-to-keep-yourself-or-a-loved-one-healthy-after-hospitalization-2019012315830 [accessed 2021-07-29]

11. Kroll RR, Boyd JG, Maslove DM. Accuracy of a wrist-worn wearable device for monitoring heart rates in hospital inpatients: A prospective observational study. J Med Internet Res 2016 Sep 20;18(9):e253 [FREE Full text] [doi: 10.2196/jmir.6025] [Medline: 27651304]

12. Welch J, Kanter B, Skora B, McCombie S, Henry I, McCombie D, et al. Multi-parameter vital sign database to assist in alarm optimization for general care units. J Clin Monit Comput 2016 Dec;30(6):895-900 [FREE Full text] [doi: 10.1007/s10877-015-9790-8] [Medline: 26439830]

13. Gallo A, Lee KA. Sleep characteristics in hospitalized antepartum patients. J Obstet Gynecol Neonatal Nurs 2008;37(6):715-721 [FREE Full text] [doi: 10.1111/j.1552-6909.2008.00297.x] [Medline: 19012722]

14. Yang CJ, Aibel K, Meyerhoff R, Wang F, Harpole D, Abernethy AP, et al. Actigraphy assessment of sleep quality among patients with acute myeloid leukaemia during induction chemotherapy. BMJ Support Palliat Care 2018 Sep;8(3):274-277. [doi: 10.1136/bmjspcare-2018-001509] [Medline: 29643104]

15. Mercer K, Li M, Giangregorio L, Burns C, Grindrod K. Behavior change techniques present in wearable activity trackers: A critical analysis. JMIR Mhealth Uhealth 2016;4(2):e40 [FREE Full text] [doi: 10.2196/mhealth.4461] [Medline: 27122452]

16. Wieringa FP, Broers NJH, Kooman JP, Van Der Sande FM, Van Hoof C. Wearable sensors: can they benefit patients with chronic kidney disease? Expert Rev Med Devices 2017 Jul;14(7):505-519. [doi: 10.1080/17434440.2017.1342533] [Medline: 28612635]

17. Kirk MA, Amiri M, Pirbaglou M, Ritvo P. Wearable technology and physical activity behavior change in adults with chronic cardiometabolic disease: A systematic review and meta-analysis. Am J Health Promot 2019 Jun;33(5):778-791. [doi: 10.1177/0890117118816278] [Medline: $\underline{30586996]}$

18. Sim I. Mobile devices and health. N Engl J Med 2019 Sep 05;381(10):956-968. [doi: 10.1056/NEJMra1806949] [Medline: 31483966]

19. Wright SP, Brown TSH, Collier SR, Sandberg K. How consumer physical activity monitors could transform human physiology research. Am J Physiol Regul Integr Comp Physiol 2017 Mar 01;312(3):R358-R367. [doi: 10.1152/ajpregu.00349.2016] [Medline: 28052867]

20. Jeffs E, Vollam S, Young JD, Horsington L, Lynch B, Watkinson PJ. Wearable monitors for patients following discharge from an intensive care unit: practical lessons learnt from an observational study. J Adv Nurs 2016 Aug;72(8):1851-1862. [doi: 10.1111/jan.12959] [Medline: 26990704]

21. Baldwin C, van Kessel G, Phillips A, Johnston K. Accelerometry shows inpatients with acute medical or surgical conditions spend little time upright and are highly sedentary: Systematic review. Phys Ther 2017 Nov 01;97(11):1044-1065. [doi: 10.1093/ptj/pzx076] [Medline: 29077906]

22. Lim SER, Ibrahim K, Sayer AA, Roberts HC. Assessment of physical activity of hospitalised older adults: A systematic review. J Nutr Health Aging 2018;22(3):377-386. [doi: 10.1007/s12603-017-0931-2] [Medline: 29484351]

23. Anderson JL, Green AJ, Yoward LS, Hall HK. Validity and reliability of accelerometry in identification of lying, sitting, standing or purposeful activity in adult hospital inpatients recovering from acute or critical illness: a systematic review. Clin Rehabil 2018 Feb;32(2):233-242. [doi: 10.1177/0269215517724850] [Medline: 28805075]

24. Yetisen AK, Martinez-Hurtado JL, Ünal B, Khademhosseini A, Butt H. Wearables in medicine. Adv Mater 2018 Jun 11:e1706910 [FREE Full text] [doi: 10.1002/adma.201706910] [Medline: 29893068]

25. Pavic M, Klaas V, Theile G, Kraft J, Tröster G, Guckenberger M. Feasibility and usability aspects of continuous remote monitoring of health status in palliative cancer patients using wearables. Oncology 2020;98(6):386-395 [FREE Full text] [doi: 10.1159/000501433] [Medline: 31336377]

26. Moher D, Liberati A, Tetzlaff J, Altman DG. Preferred reporting items for systematic reviews and meta-analyses: the PRISMA statement. PLoS Med 2009 Jul 21;6(7):e1000097. [doi: 10.1371/journal.pmed.1000097] [Medline: 19621072]

27. Mokkink LB, Terwee CB, Patrick DL, Alonso J, Stratford PW, Knol DL, et al. The COSMIN checklist for assessing the methodological quality of studies on measurement properties of health status measurement instruments: an international 
Delphi study. Qual Life Res 2010 May;19(4):539-549 [FREE Full text] [doi: 10.1007/s11136-010-9606-8] [Medline: 20169472]

28. Terwee CB, Mokkink LB, Knol DL, Ostelo RWJG, Bouter LM, de Vet HCW. Rating the methodological quality in systematic reviews of studies on measurement properties: a scoring system for the COSMIN checklist. Qual Life Res 2012 May;21(4):651-657 [FREE Full text] [doi: 10.1007/s11136-011-9960-1] [Medline: 21732199]

29. Bloch F, Gautier V, Noury N, Lundy J, Poujaud J, Claessens Y, et al. Evaluation under real-life conditions of a stand-alone fall detector for the elderly subjects. Ann Phys Rehabil Med 2011 Sep;54(6):391-398 [FREE Full text] [doi: 10.1016/j.rehab.2011.07.962] [Medline: 21903502]

30. Breteler MJM, Huizinga E, van Loon K, Leenen LPH, Dohmen DAJ, Kalkman CJ, et al. Reliability of wireless monitoring using a wearable patch sensor in high-risk surgical patients at a step-down unit in the Netherlands: a clinical validation study. BMJ Open 2018 Dec 27;8(2):e020162 [FREE Full text] [doi: 10.1136/bmjopen-2017-020162] [Medline: 29487076]

31. Kroll RR, McKenzie ED, Boyd JG, Sheth P, Howes D, Wood M, WEARable Information Technology for hospital INpatients (WEARIT-IN) study group. Use of wearable devices for post-discharge monitoring of ICU patients: a feasibility study. J Intensive Care 2017;5:64 [FREE Full text] [doi: 10.1186/s40560-017-0261-9] [Medline: 29201377]

32. Steinhubl SR, Feye D, Levine AC, Conkright C, Wegerich SW, Conkright G. Validation of a portable, deployable system for continuous vital sign monitoring using a multiparametric wearable sensor and personalised analytics in an Ebola treatment centre. BMJ Glob Health 2016 Jul 05;1(1):e000070 [FREE Full text] [doi: 10.1136/bmjgh-2016-000070] [Medline: 28588930]

33. Chiu H, Lo W, Chiang Y, Tsai P. The effects of sleep on the relationship between brain injury severity and recovery of cognitive function: a prospective study. Int J Nurs Stud 2014 Jun;51(6):892-899. [doi: 10.1016/j.ijnurstu.2013.10.020] [Medline: 24246095]

34. Lee SY, Lee KA. Early postpartum sleep and fatigue for mothers after cesarean delivery compared with vaginal delivery: an exploratory study. J Perinat Neonatal Nurs 2007;21(2):109-113. [doi: 10.1097/01.jpn.0000270627.73993.b0]

35. Razjouyan J, Grewal GS, Rishel C, Parthasarathy S, Mohler J, Najafi B. Activity monitoring and heart rate variability as indicators of fall risk: Proof-of-concept for application of wearable sensors in the acute care setting. J Gerontol Nurs 2017 Jul 01;43(7):53-62. [doi: 10.3928/00989134-20170223-01] [Medline: 28253410]

36. Weller RS, Foard KL, Harwood TN. Evaluation of a wireless, portable, wearable multi-parameter vital signs monitor in hospitalized neurological and neurosurgical patients. J Clin Monit Comput 2018 Oct;32(5):945-951. [doi:

10.1007/s10877-017-0085-0] [Medline: 29214598]

37. Watkins T, Whisman L, Booker P. Nursing assessment of continuous vital sign surveillance to improve patient safety on the medical/surgical unit. J Clin Nurs 2016 Jan;25(1-2):278-281 [FREE Full text] [doi: 10.1111/jocn.13102] [Medline: 26531215]

38. Duus CL, Aasvang EK, Olsen RM, Sørensen HBD, Jørgensen LN, Achiam MP, et al. Continuous vital sign monitoring after major abdominal surgery-Quantification of micro events. Acta Anaesthesiol Scand 2018 Oct;62(9):1200-1208. [doi: 10.1111/aas.13173] [Medline: 29963706]

39. Fuller D, Colwell E, Low J, Orychock K, Tobin MA, Simango B, et al. Reliability and validity of commercially available wearable devices for measuring steps, energy expenditure, and heart rate: Systematic review. JMIR Mhealth Uhealth 2020 Sep 08;8(9):e18694 [FREE Full text] [doi: 10.2196/18694] [Medline: 32897239]

40. Zhang Y, Weaver RG, Armstrong B, Burkart S, Zhang S, Beets MW. Validity of wrist-worn photoplethysmography devices to measure heart rate: A systematic review and meta-analysis. J Sports Sci 2020 Sep;38(17):2021-2034. [doi: 10.1080/02640414.2020.1767348] [Medline: $\underline{32552580]}$

41. Haghayegh S, Khoshnevis S, Smolensky MH, Diller KR, Castriotta RJ. Accuracy of wristband Fitbit models in assessing sleep: Systematic review and meta-analysis. J Med Internet Res 2019 Nov 28;21(11):e16273 [FREE Full text] [doi: 10.2196/16273] [Medline: 31778122]

42. Chan AM, Selvaraj N, Ferdosi N, Narasimhan R. Wireless patch sensor for remote monitoring of heart rate, respiration, activity, and falls. 2013 Presented at: 2013 35th Annual International Conference of the IEEE Engineering in Medicine and Biology Society (EMBC); July 3-7, 2013; Osaka, Japan. [doi: 10.1109/embc.2013.6610948]

43. Chan AM, Ferdosi N, Narasimhan R. Ambulatory respiratory rate detection using ECG and a triaxial accelerometer. 2013 Presented at: 2013 35th Annual International Conference of the IEEE Engineering in Medicine and Biology Society (EMBC); July 3-7, 2013; Osaka, Japan. [doi: 10.1109/embc.2013.6610436]

44. Sartor F, Papini G, Cox LGE, Cleland J. Methodological shortcomings of wrist-worn heart rate monitors validations. J Med Internet Res 2018 Dec 02;20(7):e10108 [FREE Full text] [doi: 10.2196/10108] [Medline: 29967000]
Abbreviations
BPM: beats per minute
COSMIN: Consensus-Based Standards for the Selection of Health Status Measurement Instruments 
Edited by L Buis; submitted 12.12.19; peer-reviewed by M Breteler, D Atsma, L Li, K Ng, R Eckhoff; comments to author 28.08.20; revised version received 21.10.20; accepted 15.07.21; published 18.08.21

Please cite as:

Patel V, Orchanian-Cheff A, Wu R

Evaluating the Validity and Utility of Wearable Technology for Continuously Monitoring Patients in a Hospital Setting: Systematic Review

JMIR Mhealth Uhealth 2021;9(8):e17411

URL: https://mhealth.jmir.org/2021/8/e17411

doi: $\underline{10.2196 / 17411}$

PMID:

(C) Vikas Patel, Ani Orchanian-Cheff, Robert Wu. Originally published in JMIR mHealth and uHealth (https://mhealth.jmir.org), 18.08.2021. This is an open-access article distributed under the terms of the Creative Commons Attribution License (https://creativecommons.org/licenses/by/4.0/), which permits unrestricted use, distribution, and reproduction in any medium, provided the original work, first published in JMIR mHealth and uHealth, is properly cited. The complete bibliographic information, a link to the original publication on https://mhealth.jmir.org/, as well as this copyright and license information must be included. 